\title{
Philosophical Considerations in Health: Conceptualizing to Educate-A Perspective on Neglected Tropical Diseases in Brazil
}

\author{
Dilvani Oliveira Santos ${ }^{1,2,3^{*}}{ }^{-1}$, Ludmila Veiga Faria ${ }^{1,2}$, Anna Fernandes S. C. Nascimento ${ }^{1,3}$ \\ ${ }^{1}$ Department of Molecular and Cell Biology (Institute of Biology), Laboratory of Bio-Pathogens and Cell Activation \& Educational \\ Process-Labiopac \& ProEduc, University Federal Fluminense (UFF), Niterói, Rio de Janeiro, Brazil \\ ${ }^{2}$ Graduate Program in Sciences and Biotechnology of the University Federal Fluminense (UFF), Niterói, Rio de Janeiro, Brazil \\ ${ }^{3}$ Graduate Program in Applied Microbiology and Parasitology of the University Federal Fluminense (UFF), Niterói, \\ Rio de Janeiro, Brazil \\ Email: *profa.dilvani.uff@gmail.com, ^santosdilvani@gmail.com, ludveiga2@gmail.com, annafscnascimento@gmail.com
}

How to cite this paper: Santos, D. O., Faria, L. V., \& Nascimento, A. F. S. C. (2019). Philosophical Considerations in Health: Conceptualizing to Educate-A Perspective on Neglected Tropical Diseases in Brazil. Creative Education, 10, 1125-1139. https://doi.org/10.4236/ce.2019.106085

Received: May 5, 2019

Accepted: June 15, 2019

Published: June 18, 2019

Copyright $\odot 2019$ by author(s) and Scientific Research Publishing Inc. This work is licensed under the Creative Commons Attribution International License (CC BY 4.0).

http://creativecommons.org/licenses/by/4.0/

\begin{abstract}
This paper aims to recover the history of health concept evolution from its birth in Ancient Greece to the contemporary days, drawing an overview of the firsts philosophical thoughts about health in distinctive historical periods, analyzing how this concept has been impacted by knowledge improvement and both research and technological discoveries over time. In order to understand the persistence of Neglected Tropical Diseases which causes physical disabilities and social discrimination, this paper will focus on Leprosy and Cutaneous Leishmaniasis and its relation to social inequality mainly in developing countries. These approaches on the understanding of the health-disease binomial are necessary to reflect on health in the course of human history and, from there, to promote joint actions both in the area of scientific research and health education.
\end{abstract}

\section{Keywords}

Philosophy, Health, Education, Leprosy, Cutaneous Leishmaniasis

\section{A Philosophical Vision of the Health Concept Evolution}

It was in Ancient Greece, that health was conceptualized under the influence of both philosophy and medicine. It is widely known that Greece, is considered the cradle of these two sciences already in the fifth century before Christ (bC). Philosophy, for example, reaches its apogee with Socrates, Plato and Aristotle, 
where they have consolidated the rationale on which Western knowledge is based on. The philosophical thought of Socrates, Plato and Aristotle, greatly influenced Hippocrates, another Greek philosopher, who later became a physician.

Hippocrates' father was also a scientist who practiced health care (Salis \& Silva, 2003). It is possible that all those external influences have contributed to mobilizing Hipocrates towards many medical discoveries at his historical period. Nowadays, this great philosopher is considered the symbol of medicine and his words became known as "You are what you eat" as well as the Hippocratic Oath" which is read in all medical graduation ceremonies, at all Universities throughout the world, whether in an integral or summarized form.

Curiously, the Hippocratic Oath ${ }^{1}$, mentions other Greek philosophers such as Apollo, Aclepius, Hygeia and Panakeia, who have their story told in Greek mythology as below mentioned.

\section{${ }^{2}$ The legendary birth of Asclepius}

It is known that Asclepius was the son of the god Apollo with a mortal woman named Coronis. While Coronis was pregnant, she fell in love with Ischys, another mortal man. When Apollo learned of this relationship, he ordered Artemis to kill Coronis. In fact, Apollo witnessed the murder scene and felt guilty for killing his son. He then saved the baby, opening the womb of Coronis. It is believed that this was the first case of cesarean section in the history of humanity. Asclepius grew up healthy and became a qualified medical doctor

(https://www.greeka.com/greece-myths/asclepius.htm). Afterward, Asclepius married and had two daughters: Hygeia and Panakeia which followed the skills of their father Asclepius in the health researches (https://www.greeka.com/greece-myths/asclepius.htm) (Figure 1).

Panakeia, her sister (Hygeia), his father (Asclepius) and his grandfather (Apollo) appear in the oath of Hippocrates ${ }^{1}$, which is cited by the newly formed physicians at the time of their graduation ceremony, as previously mentioned:

1"I swear by Apollo medical doctor and Asclepius and Gednaea and Panacea and all the gods and goddesses, making them my witnesses that I will follow this oath and covenant according to my ability and oath"

(Salis \& Silva, 2003)

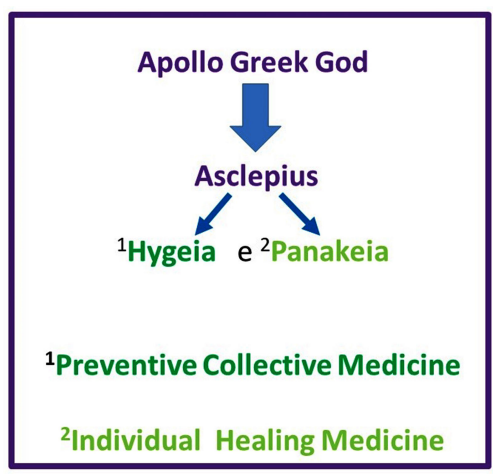

Figure 1. Relevant issues to consider the emergence of the concept of preventive medicine and curative medicine. 
Philosophy has been spread throughout the world and right after Christ $(\mathrm{aC})$; thus, in the Roman empire, another philosopher named Galen (131-201 aC), believed that the body was only a vehicle for the soul and that God defined body functions as the thought of Aristotle (Rhodes, 1985). These ideas were accepted by both Islam and Christianity, since this still accompanied the thoughts of Hippocrates in relation to the four moods: the four elements of nature (earth, water, air and fire) exist in proportions not only in the world but, also, in the human body, and correspond to specific functions. The earth is dry and cold, and corresponds to black bile, The water is wet and cold, and represents the phlegm; The air is wet and warm, and corresponds to the blood; The fire is dry and warm, and corresponds to the yellow bile (Salis \& Silva, 2003).

Hippocrates' thoughts about the four moods have influenced the Italian philosopher-Galen. And, interestingly, even today, one of Galen's knowledge is used, such as for example: an expert measure, of a medical-legal nature; called "Hydrostatic Docimasia of Galen". The word "docimasia" comes from the Greek dokimasia (experience, proof). It is an expert measure, of medical-legal nature, applied with the purpose of verifying if a child is born alive or dead and, therefore, whether arrives to breathe. In legal terms, docimasia is quite relevant because it contributes to the determination of the moment of death. If the person comes to the living or dead light, the legal consequences will be different in each case (Rhodes, 1985).

In another part of the world, in Egypt, Hypatia, a philosopher born in $355 \mathrm{aC}$, was the first woman to study Law and defended, among other things, the right to Health Promotion, following the binomial "Healthy mind, healthy body". Even with the lack of written work, Hyphatia is widely recognized by scholars and her fame has survived up to the present moment. Many of the works commonly attributed to her are believed to have been collaborative work with her father, Téon de Alexandria. This type of authorship uncertainty is typical of female philosophers in Antiquity (Dzielska \& Lyra, 1996).

In the Persian Empire, Avicenna (980-1037 aC), another great physician who followed the line of Aristotle can be cited for having had made an influence on the concept of health. Thus, people of Arab origin, made huge progress in the area of Medicine, mainly using the technique of mummification of bodies. The most famous works of Avicenna is the "Book of Healing" and the "Canon of Medicine" which was the text used in medieval universities such as the University of Montpellier and the Catholic University of Leuven. Avicenna presents a complete system of medicine according to the principles of Galen and Hippocrates (Souza, 2002).

At the time of the Cultural Renaissance, around the fifteenth century, medicine became prosperous. André Vésale, born in Brussels, Belgium, on 1514, was an anatomist and physician, considered by many historians of science as the greatest anatomist of the Renaissance, or even the greatest in history of medicine. He is the author of De humani corporis fabrica (On the Functioning of the 
Human Body), one of the most innovative books on human anatomy. He was also a great humanist of his time. His works, in addition to bringing anatomy into modernity, was contrary to the one of the dogmas of galenism that blocked scientific evolution for more than a thousand years both in Europe and in the Islamic world. Vesalius was not entirely against Galen's work, for which he had great admiration. However, he criticized some ideas from Galeno, to point out some of his mistakes.

Back in Italy, Leonardo da Vinci was one of the most important figures of the Renaissance era, which stood out as a scientist, mathematician, engineer, inventor, anatomist, painter, sculptor, architect, botanist, poet and musician. Leonardo was often described as the archetype of the Renaissance man, someone whose insatiable curiosity was matched only by his inventiveness. He was more knowledgeable than the doctors themselves, and impressed everyone with his masterful mastery of bones, muscles, nerves, and vessels (Kickhöfel, 2011).

In England, in the seventeenth century, William Havery discovered the circulatory system of blood, giving a better understanding of physiology and anatomy. In the 19th century, Louis Pasteur discovered that the disease was originated from bacteria (Salis \& Silva, 2003). At the same time, the "sanitary police" was adopted as a health policy, where healthy people were coerced by the police to take appropriate health behaviors. In addition, there was isolation of the sick individuals, what happened to the lepers who were completely segregated from the social coexistence with relatives and friends. With these drastic measures, medicine directed its actions towards the disease and the body in order to reach a normal biological state, according to the beliefs of that time.

In the nineteenth century, with the development of medicine, modernization, technological advancement and the expansion of information through the media provided the population with access to the social determinants of health (Salis \& Silva, 2003).

\section{Evolution on the Concept of Health in the 20 ${ }^{\text {th }}$ Century}

The 20th century was marked by progress characterized by models of confrontation with social inequalities and injustices that affected the world population (Heidmann et al., 2006). And it was in the post-war period, 1946, that the World Health Organization (WHO) was created and exposed a concept that compared the human body to a machine. According to the WHO, the health was responsible by the good functioning of machine, that is, the human body. Actually, in this period, health began to be collective obligation and not individual anymore. In fact, WHO was created by the United Nations (UN) and its headquarters is in Geneva, Switzerland.

The World Health Organization (WHO) has fostered several discussions and argued that "The right to health is the responsibility of the state" (Canguilhem, 1990). In addition, WHO conceptualized Health as "the state of most complete physical, mental and social well-being, and, not only the absence of disease". This new concept, became more expressive on April 7, 1948, date that came to 
be celebrated World Health Day.

Moreover to WHO's activities for health promotion, we should also mention the Ottawa Letter, a product of the International Conference on Health Promotion, in Ottawa, Canada, in 1986, which brought the "idea of health related to the quality of life relativized by different factors: food, shelter, education, stable ecosystem, equity, social justice, income, economic resources, sustainable resources and peace (World Health Organization (2007). II. Title: Making a Difference-30 Years of Research and Capacity Building in Tropical Diseases. doi:10.2471/TDR.07.978-924-1595575). And, this new concept of health established by WHO is closely linked to the thoughts of all philosophers mentioned above: Hippocrates correlated good nutrition to health as well as the existence of an interconnected system between environment and body systems on humans; Asclepius and his daughters (Hygeia and Panakea) intuited preventive and curative medicine; Galen demonstrated the importance of air (of breathing) for survival; Hypatia intuited that a healthy mind leads to a healthy body. Meanwhile, Avicena, Vesalius, da Vinci, Havery and Pasteur were the precursors on observations and trials related to the disease and, thus, compared them to the state of health.

The VIII National Health Conference, which took place in Brazil in 1986, mentioned that "The right to health means the guarantee by the State of dignified living conditions and universal and equal access to the actions and services of promotion, protection and recovery of health, at all levels, to all inhabitants of the national territory, leading to the full development of the human being in his/her individuality (World Health Organization (2007). II. Title: Making a Difference-30 Years of Research and Capacity Building in Tropical Diseases. doi:10.2471/TDR.07.978-924-1595575).

In addition, it is worth considering that Brazil has had a fundamental role in the history of the WHO and have been contributing to the WHO to raise global health standards. WHO's creation proposal was written by delegates and some of them, were representing Brazil, who proposed the establishment of an international public health organization with a global reach. Since then, Brazil and WHO have developed extensive collaboration. The Prof. Dr. Marcolino Candau, from University Fluminense Federal (UFF), Niterói, Rio de Janeiro, Brazil, was the second WHO general director for 20 years (1953 to 1973)

(http://munksroll.rcplondon.ac.uk/Biography/Details/740).

Furthermore, Dr. Dilvani Santos from the University Federal Fluminense, RJ, Brazil, was the lead researcher for a WHO funded project (Cytokines profile in Leprosy ID 931100) in collaboration with Innogenetics, Ghent, Belgium (1994-1998) and Leprosy Unit (Fiocruz, RJ, Brazil), having formed two important products in the field of Leprosy-the pioneer discovery of the reversal of immunological anergy often observed in Leprosy, through "in vitro" experiments demonstrating that dendritic cells from lepromatous Leprosy patients stimulated autologous lymphocytes, which in turn, responded successfully to Mycobacterium leprae infection. This work suggests the use of dendritic cells as 
a form of immunotherapy in Leprosy (Santos et al., 2001). Secondly, still within the collaboration with WHO, they discovered a biomarker (B7) for the early diagnosis of reactional episodes in Leprosy. This work was very important, since the lack of early diagnosis of reactional episodes in Leprosy could lead the patient to death (Santos et al., 2007).

And, at the Oswaldo Cruz Foundation (FIOCRUZ), Rio de Janeiro, Brazil, Dr. Carlos Morel was director of the WHO Special Program for Research and Training in Tropical Diseases (TDR) from 1998 to 2004

(https://www.who.int/tdr/publications/documents/anniversary_book_phase3.pd f?ua=1).

However, despite the invaluable efforts of the WHO, progress in the area of Health was facing some difficulties for the feasibility of some research projects, especially in developing countries. Thus, even today, we perceive the social inequalities that prevent access to both health services and health information services, we understand the need for health in various ways, and how far away are the effective actions of health promotion and protection, especially in developing countries. When we think about health, we must understand that health is a result of the circumstances that involve: food, education, employment, housing, income, transportation, work, leisure, employment, freedom, access to land and access to health services, forms of social organization and production.

However, these circumstances can create social inequalities in living standards. Health Promotion letters include the reference documents resulting from the process of discussion and collective elaboration of the essential concepts on the subject. Health Promotion proposition comprises health as a social production and, in this way, involves a space of action that goes beyond the health sector. The perception of health seen only through the biological relation cannot be considered, since its historical relation is fundamentally in face of social influence and culture in which it is introduced.

At present, with the economic changes resulting from the process of globalization and the consequences of capitalism, there is the appreciation of competitiveness and individualism. These characteristics also influenced the evolution of the concept of health, which had a significant impact on the transformations that occurred with the evolution of humanity.

It is worth mentioning that disciplines designed to investigate and understand health of populations (the social and behavioral sciences) are not the same as the basis for understanding the disease and its treatment (the biological sciences). The fundamental sciences that help to identify, prevent and treat diseases are mainly based on the biological functions of the human being. They analyze each of their components in a scientific way to understand the biological mechanisms of life and pathology (Canguilhem, 1978). In relation to the human sciences, they aim at understanding man in society. The analysis is done through individuals in their groups and on the relationships between social groups (family, community, society, humanity).

However, it is due to the individual, as a social and biological being, that these 
two areas of expertise can match. At present, it is widely recognized that both biological and psychosocial being are related-neurology, psychology, and immunology-report the biological communication systems that exist between the central nervous system and the immune system, strengthening the work of psychologists and psychoanalysts about the mutual effects of the mind on the body according to the convictions of Hypatia, a philosopher born in 355 bC in Egypt, as previously cited.

But regrettably, general society has not yet been educated to fully assimilate the importance of social context, and its broadest sense and complexity, to promote actions on individuals' health care. Health promotion had already been conceptualized traditionally, having been defined (Leavell \& Clarck, 1976) as fundamental in the primary level of attention in preventive medicine. Over time, this concept has gained more prominence, especially in Canada, USA and Western European countries.

Even in this circumstance, the proper understanding of what prevention and promotion differ from each other is precisely the awareness about the uncertainty of scientific knowledge which is not simply a technical limitation that can be successively overcome (Czeresnia, 1999). The longing for health is an issue not only of survival but of qualification of existence (Santos, 1987). It is something that leads us to the social, existential and ethical dimension, to a specific trajectory exposed to concrete situations, to the active engagement and commitment of the subjects, who dedicate their particularity to putting knowledge at the service of what is not understood in the search for truth which emerges from the lived experience (Badiou, 1995). To analyze, therefore, the terms of health promotion is to understand that behavioral changes are driven simultaneously by what is known about determinisms and by the clarity that it is not known, knowing that it will not even come to be known, all of them (Badiou, 1995).

The understanding of "health-disease" binomial is necessary for the proposal of a common qualification that can clarify the concept of health in the course of human history. From the beginning, human being asked about the origin of life and the concept of health and disease. The sphere of Health Promotion calls us to reflect on the obligation of the concept of preservation of health, of all humanity equally, in the essence of going further from the exercise of preventive and curative medicine.

In this context, the most current concept of Health Promotion according to WHO is defined by the following statement: Health promotion is the process of empowering people to increase health control and improve it (9th Global Conference on Health Promotion Shanghai, 2016). The priority is health and respect for equal rights, based on the central responsibility of the governments of their peoples, affirming the urgent and urgent need for a coherent, effective health and well-being policy and recognizing that this will require policy, courage and strategic vision (Atlan, 1991).

Currently, the life expectancy of the population has increased and people has more access to technological advances almost in every sphere of the world. 
Unfortunately, social inequalities persist, especially in developing countries (http://www.who.int/healthpromotion/conferences/9gchp/en; Barreto, 2017). Specially in Brazil, between 2001-06, luckily, it has been estimated that falling labour income inequality accounted for half the inequality fall, driven by strong employment and income growth and falling returns to secondary and tertiary education (Simson, 2018).

Back to the origin of Medicine that was undoubtedly through the Philosophy, as mentioned at the beginning of this article, we clearly see that by distancing itself from its philosophical origin, the Medicine has undergone a process of "dehumanization". In view of it, the technological advances have not been accompanied by advances on the social scale. According to Lee, 2004, p. 1 apud in (Lopez-Calva et al., 2013), the challenges of protecting and promoting health is inherently a political one-questioning "whose health needs should be addressed and how should available resources be allocated" (Lopez-Calva et al., 2013). According to the many lasted scientific research, revised by Sidsel Roalkvam \& Desmond McNeill (2016) the Ebola crisis brought to the fore an ongoing controversy in global and international health about vertical versus horizontal approaches to health improvement. Vertical approaches are generally disease specific and promote targeted clinical interventions delivered by a specialized service. Horizontal approaches, by contrast, tackle several interrelated health issues by strengthening health systems and developing integrated delivery systems (Roalkvam \& McNeill, 2016). This debate has focused especially on early vaccine initiatives and the more recent impact of global health initiatives such as GAVI and the Global Fund to fight AIDS, TB and Malaria (Behague \& Storeng, 2008), but this is only two manifestations of a serious and more wide-ranging problem affecting health systems as a whole, in many countries of the world.

To put it briefly, the progress is not linear, which raises the need to think about the quality and sustainability of human development. And, this scenario contributes to the prevalence of several pathologies spread throughout the world, including Neglected Tropical Diseases as a whole, and in this work, we will focus on Leprosy and cutaneous Leishmaniasis, especially in Brazil, since they are pathologies that, if not treated, can lead to physical disabilities and social discrimination.

\section{How Can Health Education Be Used as a Strategy for the Control of Neglected Tropical Diseases? Leprosy and Cutaneous Leishmaniasis as a Model}

Neglected Tropical Diseases (NTDs) are endemic in countries characterized by problems of basic sanitation, socio-economic deficit and little investment of the large pharmaceutical industries to treat these diseases (Hanefeld, Spicer, Brugha, \& Walt, 2007). In addition, ineffectiveness or lack of investment in health education measures should be taken into account. Thus, developing continents such as Africa and South America, ranging from rural areas to urban slums, are routinely scenarios of neglected tropical diseases in endemic form (Morel, 2006; 
Camargo, 2008).

Note, in Figure 2, it is shown the ranking list of some Neglected Tropical Diseases and their incidence in the world, according to data available on WHO's official website. In 2012, diseases such as AIDS, Tuberculosis and Malaria are at the top of the list of priorities. And Leishmaniasis was on the list, followed by Leprosy as well. Interestingly, in the WHO reports, three years later, AIDS, tuberculosis and malaria did not appear in the ranking list anymore, while Leishmaniasis and Leprosy are still in their priorities, such as Chagas disease, dengue and schistosomiasis (Annual Reports WHO, 2015).

Such public health problems generate negative impacts in several areas, since they are usually chronic and debilitating diseases that make it impossible for individuals to work and perform their daily activities. They generate stigmas that only fuel the continuing cycle of poverty. Although this scenario begins to change with stimuli and programs of government and non-governmental organizations (NGOs) with work in the area of Health Education, with a focus on prevention and control of Neglected Tropical Diseases (NTDs), the overall picture is far to be reversed in the short-term "eradication of these diseases" (Morel, 2006; WHO, 2012).

Among NTDs, Leprosy and Leishmaniasis account for almost 2 million new cases per year worldwide (WHO, 2015). Although, they are caused by different pathogens, some cutaneous symptoms are very similar.

Leprosy has two etiological agents: Mycobacterium leprae (Bechler, 2012) and the bacillus M. lepromatosis (Han et al., 2008).

In the case of Cutaneous Leishmaniasis, the etiological agent is Leishmania sp. (several different species), together with the vectors that are transmitting insects, affects humans and other animals such as dogs (Camargo, 2008). Both diseases

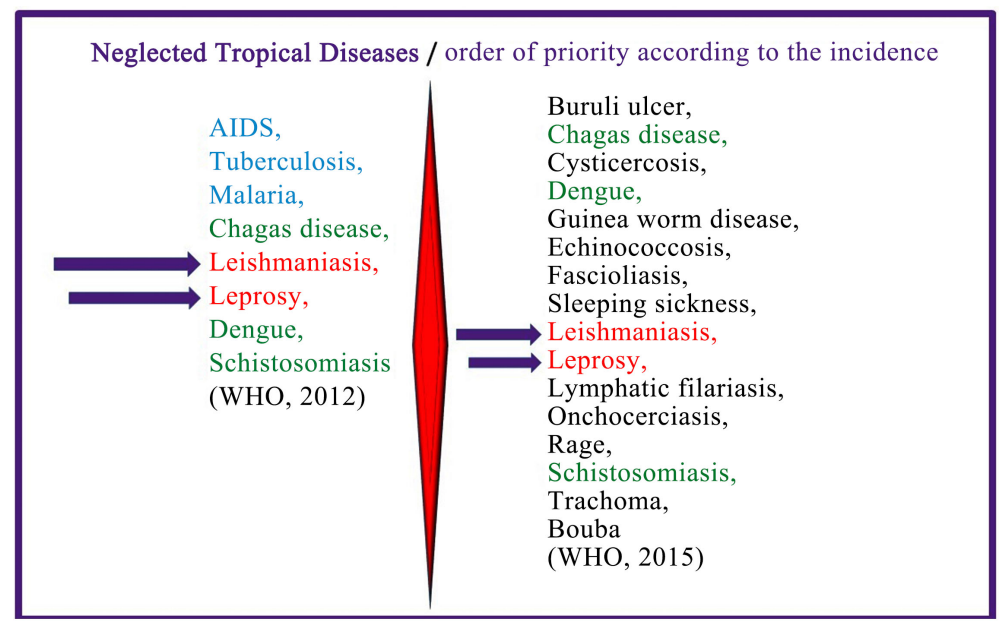

Figure 2. Ranking list of some Neglected Tropical Diseases spread in the world, according to incidence rates reported by WHO (2015). AIDS, Tuberculosis and Malaria are not in the ranking list of priorities in 2015, anymore, while Chagas Disease and Dengue migrated to the top of this list in 2015. Leishmaniasis and Leprosy (diseases which cause physical disabilities) also remained included in those lists (2012 and 2015). 
have the skin as one of the main targets for the manifestation of symptoms, however, Leprosy also causes lesions in the peripheral nervous system, in addition to the typical skin lesions (Scollard et al., 2006).

Regarding Health Education issues in Leprosy, Lennon, J.L. (1988) mentioned that in the Post-Congress Workshop on Health Education in 1984, the Gandhi Memorial Leprosy Foundation, the following policy statement was reached on Health Education in Leprosy. They stated:

[...] Health education refers to the process of assimilation of knowledge, attitudes and scientific behavior in health in the culture of people. Health education in the objectives of Leprosy, ensures community participation in Leprosy control programs. Healthy education, therefore, addresses the patients, their families, the community and all components of health services" [...].

(Adiga, R.G. 1984 APUD Lennon, J. L. 1988)

[...] Health education should produce behavioral changes in overcoming the sociocultural aspects of Leprosy stigma, identification and recognition of the disease, continuation of antileproic therapy and promotion of rehabilitation (both social and physical) [...]

(Giri, S.K. 1976 APUD Lennon, J.L. 1988)

In other words, health education refers to the process of acquisition of information concerning to the health conceptualizing to educate people about a health issue.

Annual statistics for Leprosy in 2017 were officially received from 159 countries from all regions of the World Health Organization (WHO), with a prevalence register of 0.25 per 10,000 population with 192,173 cases of Leprosy in treatment by the end of 2017. During the year, 210,671 new cases (2.8 per 100,000 inhabitants) were reported globally. Of these, $12,189(6 \%)$ of the cases had visible deformities or grade 2 of physical disability, including 238 children, which is very worrying.

(www.searo.who.int/entity/global_Leprosy_programme/epidemiology/en).

Currently, all Latin American countries have Leprosy, with the exception of Chile, and Brazil is the country with the highest prevalence, being the second country in the world in the greatest number of cases of the disease, losing only to India presenting the greatest number of cases of Leprosy in the world (WHO, 2015). However, Leprosy, is one of the oldest disease and the most marginalized illness in human history, its transmission mechanism is unknown until today. However, its pathogenesis is well studied and known and can be controlled as long as its endemic areas are treated with measures preventive and appropriate measures of public health. Since the introduction of free multi-drug therapy (MDT), cases of Leprosy have reduced from more than 5 million cases in the mid-1980s to less than 200,000 in the present. Nevertheless, some people still erroneously believe that Leprosy is incurable, which leads to fear of the disease (https://www.paho.org).

However, Brazil is one of the three countries with the highest number of reported cases worldwide, recorded 26,875 new cases in 2017 (contributing more 
than $90 \%$ of the burden of diseases in the Americas) (https://www.paho.org). These data justify the maintenance of the level of attention and care for Leprosy in Brazil and the dissemination of this disease using information as a prophylactic measure.

One of the major problems of Leprosy is the prejudice that prevents the search for notification, diagnosis and treatment, which fuels a vicious cycle of contagion and a propensity for physical disabilities. In addition, the treatment for Leprosy may lead to the appearance of reactional episodes (manifestations of acute inflammatory responses) that, if not specifically treated, can lead to death.

In relation to cutaneous Leishmaniasis, in most cases, they are zoonoses caused by the protozoan of the genus Leishmania, transmitted by the dipteran vector of the Phlebotominae subfamily, of the genus Phlebotomus in the Old World and by the genus Lutzomyia, in the New World (Camargo, 2008; Santos et al., 2008).

Leishmaniasis is a chronic and debilitating sickness and still has a significant impact on the health and economy of developing countries, and similar to Leprosy, can also lead to physical disabilities. In addition, Leishmaniasis is a continuing concern even in developed countries, due to the possibility that it may affect tourists from countries where the parasite is endemic (Santos et al., 2008). It is worth mentioning that in addition to Africa and Latin America, Leishmaniasis occurs in many regions of the Iberian Peninsula, in addition to Italy, Turkey and Greece (Camargo, 2008).

It is worth noting that the incidence of Leprosy, as well as other neglected diseases, is also directly related to the low "Human Development Index" (HDI), which is used by the United Nations to analyze the quality of life of population. In Brazil, the total number of new Leprosy cases shows a total of 26,875 cases per year (Sinan/SVS, 2018). According to WHO 2015,

(https://www.who.int/Leishmaniasis/burden/Status_of_endemicity_of_CL_worl dwide_2015_with_imported_cases.pdf?ua=1\&ua=1) Leishmaniasis is considered endemic in 88 countries, with more than 12 million people presenting with this disease complex and a portion of the population of approximately 350 million at risk of infection.

Therefore, in spite of all the efforts of the world research on scientific advances in these two areas, searching for new forms of treatment for Leprosy and Leishmaniasis, as well as the accumulated knowledge about these pathologies during all these years, these two diseases still remain as a challenge.

It is of fundamental importance to reflect that, in addition to research aimed at more specific treatments (less toxic, more effective and low cost treatments), these diseases require urgent investments in the area of Health Education, such as scientific dissemination through educational campaigns: How is the form of your acquisition? How are the treatment regimens? How can they be prevented? These issues should be addressed primarily to people of low income and low education, who are, in fact, the largest public affected by these pathologies. Certainly, health education will become a priority need in programs against these 
Neglected Tropical Diseases or others, where the affected individuals will not become persons with physical disabilities and will not suffer social prejudices, as in the specific case of these two serious diseases: cutaneous Leishmaniasis and Leprosy.

\section{Conclusion}

This article briefly mentioned the history of the evolution on health concept since the source of philosophy till the 20th century with the creation of the World Health Organization. And in this context, some Neglected Tropical Diseases were illustrated. One of the oldest diseases in the history of mankind-Leprosy, which has been confused with cutaneous Leishmaniasis and other skin diseases long time ago, because of the similarity with cutaneous lesions of other origins, was briefly mentioned. Leprosy has a cure and the intense knowledge about this millenary pathology needs to be widely diffused in the world for all people, regardless of age and degree of study. Especially up-to-date knowledge about the diagnosis and treatment of this disease can also contribute to the demystification of the stigma associated with it, especially in Brazil.

Concerning to cutaneous Leishmaniasis, the treatment uses topical creams (mainly for children) and is currently available in clinical trials (Hotez et al., 2016). According to the natural cycle of Leishmaniasis, its control can also be done through the control of vectors and the disease's natural reservoirs. The continuous evaluation of control measures in endemic environments, together with population education programs are essential as measures to control and prevent Leishmaniasis.

It is worth mentioning that, both diseases can lead to psychological disturbs associated with the deformities. Furthermore, women and children living in unhealthy environments represent the most vulnerable population to these NTDs.

We hope this article will encourage scientists and educators to create scientific and academic products that address scientific dissemination about these and other pathologies, in the context of Health Education. This will be achieved through the implementation of awareness campaigns that will be responsible for improving the capacity to intensify and maintain Leprosy and Leishmaniasis control activities through the establishment or strengthening of institutions that carry out regular courses on diagnosis and treatment of these sicknesses. The organization of training workshops as well as organization of annual meetings of national programs that, in addition to informing knowledge, produce material in the educational area with easy access to the population such as booklets, websites, manuals and textbooks (specially addressed to children through short stories) can contribute to the elimination of stigma and discrimination against persons affected by Leprosy and Leishmaniasis and their families. And finally, special care should be done to the occurrence of Leprosy and Leishmaniasis on less developed areas and vulnerable populations mainly children.

Finally, through the simultaneous work of Education and Scientific Research, 
we believe that the two main pillars to elimination the NTDs, proposed by the World Health Organization could be reached. The great challenge for educators and/or researchers is to ensure that both experimental research and health education can effectively contribute to the eradication of some NTDs in the world. And to achieve this, Education is the way-this practically depends on the re-education of educators and/or researchers together with education of the population affected or not by these pathologies.

\section{Acknowledgements}

We would like to thank the Universidade Federal Fluminense (UFF), Coordenação de Aperfeiçoamento de Pessoal de Nível Superior (CAPES), Programa de Pós-Graduação em Microbiologia e Parasitologia Aplicada (UFF), Programa de Pós-Graduação em Ciências e Biotecnologia (UFF) for the constant stimulus to work in the educational area. Thanks also to Clara Maria Santos de Lacerda (CAE-Certificate in Advanced English-University of Cambridge-UK 2019) for the careful review of this article.

\section{Conflicts of Interest}

The authors declare no conflicts of interest regarding the publication of this paper.

\section{References}

Atlan, H. (1991). Tudo, Não, Talvez: Educação e verdade. Lisboa: Instituto Piaget.

Badiou, A. (1995). Ética: Um ensaio sobre a consciência do mal. Rio de Janeiro: Relume.

Barreto, M. L. (2017). Health Inequalities: A Global Perspective Ciênc. Saúde Coletiva, 22, 2097-2108. https://doi.org/10.1590/1413-81232017227.02742017

Bechler, R. G. (2012). Hansen versus Neisser: Controvérsias científicas na “descoberta” do bacilo da lepra. História, Ciências, Saúde-Manguinhos, Rio de Janeiro, 19, 815-841. https://doi.org/10.1590/S0104-59702012000300003

Behague, D. P., \& Storeng, K. (2008). Collapsing the Vertical-Horizontal Divide: An Ethnographic Study of Evidence-Based Policymaking in Maternal Health. American Journal of Public Health, 98, 644-649. https://doi.org/10.2105/AJPH.2007.123117

Camargo, E. P. (2008). Doenças Tropicais. Estudos Avançados, 22, 95-110. https://doi.org/10.1590/S0103-40142008000300007

Canguilhem, G. (1990). La Santé: Concept vulgaire e question philosophique. Paris: Sables.

Canguilhem, G. O. (1978). Normal e o Patológico. Rio de Janeiro: Forense-Universitária.

Czeresnia, D. (1999). The Concept of Health and the Difference between Promotion and Prevention. Cadernos de Saúde Pública, 15, 701-709. https://doi.org/10.1590/S0102-311X1999000400004

Dzielska, M., \& Lyra, F. (1996). Hypatia of Alexandria. Cambridge, MA: Harvard University Press.

Han, X. Y., Seo, Y.-H., Sizer, K. C., Schoberle, T., May, G. S., Spencer, J. S., Li, W. and Geetha Nair, R. (2008). A New Mycobacterium Species Causing Diffuse Lepromatous Leprosy. American Journal of Clinical Pathology, 130, 856-864. 
https://doi.org/10.1309/ajcpp72fjzzrrvmm

Hanefeld, J., Spicer, N., Brugha, R., \& Walt, G. (2007). How Have Global Health Initiatives Impacted on Health Equity: What Strategies Can Be Put in Use to Enhance Their Positive Impact and Mitigate against Negative Impacts? A Literature Review Commissioned by the Health System Knowledge Network.

http://www.who.int/social_determinants/resources/csdh_media/global_health_initiativ es_2007_en.pdf

Heidmann, I. T., Almeida, M. C., Boehs, A. E., Wosny, A. M., \& Monticelli, M. (2006). Promoção à saúde: Trajetória histórica de suas concepções. Texto Contexto Enfermagem, 15, 352-358. https://doi.org/10.1590/S0104-07072006000200021

Hotez, P. J., Pecoul, B., Rijal, S., Boehme, C., Aksoy, S., Malecela, M., Tapia-Conyer, R., \& Reeder, J. C. (2016). Elimination of Neglected Tropical Diseases: Translational Sciences and New Technologies. PLOS Tropical Diseases Neglected, 10, e0003895.

https://doi.org/10.1371/journal.pntd.0003895

Kickhöfel, E. H. P. (2011). A ciência visual de Leonardo da Vinci: Notas para uma interpretação de seus estudos anatômicos. Scientiæ Zudia, 9, 319-355. https://doi.org/10.1590/S1678-31662011000200005

Leavell, S., \& Clarck, E. G. (1976). Medicina Preventiva. São Paulo: McGraw-Hill.

Lennon, J. L. (1988). A Review of Health Education in Leprosy. International Journal of Leprosy, 56, 611-618.

Lopez-Calva, N. et al. (2013). The Impact of Taxes and Social Spending on Inequality and Poverty in Argentina, Bolivia, Brazil, Mexico and Peru: A Synthesis of Results. Working Paper 311, Washington DC: Center for Global Development. http://www.commitmentoequity.org/publications_files/CEQWPNo13\%20Lustig\%20et \%20al.\%20Overview\%20Arg,Bol,Bra,Mex,Per,Ury\%20April\%202013.pdf

Morel, C. M. (2006). Inovação em saúde e doenças negligenciadas. Cadernos de Saúde Pública, 22, 1522-1523. https://doi.org/10.1590/S0102-311X2006000800001

Rhodes, P. (1985). An Outline History of Medicine. London: Butterworths.

Roalkvam, S., \& McNeill, D. (2016). What Counts as Progress? The Contradictions of Global Health Initiatives. Forum for Development Studies, 43, 69-88. https://doi.org/10.1080/08039410.2015.1134645

Salis, L. H. A., \& Silva, S. N. A. (2003). Medicina: Quando a arte, a ciência e a tecnologia se associam para cuidar das pessoas. Revista Brasileira de Cardiologia, 15, 157-166.

Santos D., Coutinho, C. E. R., Madeira, M. F., Bottino, C. G., Vieira, R. T., Nascimento, S. B., Bernardino, A., Bourguignon, S. C., Corte-Real, S., Pinho, R. T., Rodrigues, C. R., \& Castro, H. C. (2008). Leishmaniasis Treatment-A Challenge That Remains: A Review. Parasitology Research, 103, 1-10. https://doi.org/10.1007/s00436-008-0943-2

Santos, B. S. (1987). Um discurso sobre as ciências. Porto: Afrontamento.

Santos, D., Sandra, S. L., Esquenazi, D., Nery, J. A., Defruyt, M., Lorré, K., \& Van Heuverswyn, H. (2001). Evaluation of B7-1 (CD80) and B7-2 (CD86) Costimulatory Molecules and Dendritic Cells on the Immune Response in Leprosy. Japanese Journal of Leprosy: Official Organ of the Japanese Leprosy Association, 70, 15-24. https://doi.org/10.5025/hansen.70.15

Santos, D., Van Heuverswyn, H., Nery, J. A., Bourguignon, S., Castro, H., Rangel, C., \& Miranda, A. (2007). Expression of B7-1 Costimulatory Molecule in Lepromatous Leprosy and Reactional Episodes. Clinical and Experimental Dermatology, 32, 75-80. https://doi.org/10.1111/j.1365-2230.2006.02291.x

Scollard, D. M., Adams, L. B., Gillis, T. P., Krahenbuhl, J. L., Truman, R. W., \& Williams, 
D. L. (2006). The Continuing Challenges of Leprosy. Clinical Microbiology Reviews, 19, 338-381. https://doi.org/10.1128/CMR.19.2.338-381.2006

Simson, R. (2018). Mapping Recent Inequality Trends in Developing Countries, Working Paper. London: International Inequalities Institute, the London School of Economics and Political Sciences.

http://www.lse.ac.uk/International-Inequalities/Assets/Documents/Working-Papers/III -Working-Paper-24-mapping-recent-inequality-trends-in-developing-countries.pdf

Souza, P. R. H. (2002). Avicenna: A Viagem da Alma (p. 39). São Paulo: Perspectiva.

WHO (2012). Organização Mundial da Saúde, 2012. Primeiro relatório da OMS sobre doenças tropicais negligenciadas: Avanços para superar o impacto global de doenças tropicais negligenciadas.

World Health Organization (2007). Title: Making a Difference: 30 Years of Research and Capacity Building in Tropical Diseases.

World Health Organization (2015). Annual Reports I.

http://munksroll.rcplondon.ac.uk/Biography/Details/740

http://www.searo.who.int/entity/global_Leprosy_programme/epidemiology/en

http://www.who.int/healthpromotion/conferences/9gchp/en

https://www.greeka.com/greece-myths/asclepius.html

https://www.theoi.com/Ouranios/Asklepios.html

https://www.who.int/Leishmaniasis/burden/Status_of_endemicity_of_CL_worldwide_20

15_with_imported_cases.pdf?ua $=1 \& u a=1$

https://www.who.int/tdr/publications/documents/anniversary_book_phase3.pdf?ua=1 